\title{
A política de leitura em campinas: o caso da biblioteca municipal "Prof. Ernesto Manoel Zink"
}

\author{
Sérgio Antonio da Silva Leite \\ Universidade Estadual de Campinas \\ Faculdade de Educação \\ Campinas - SP - Brasil

\section{Luciane Vaughn Schmidt} \\ Rede Municipal de Campinas \\ Campinas - SP - Brasil \\ e-mail: sasleite@uol.com.br
}

\section{Resumo}

A dinâmica de funcionamento da Biblioteca Municipal "Prof. Ernesto Manoel Zink" relaciona-se com uma problemática maior: investigar se esse espaço público tem representado, para os moradores de Campinas, uma possibilidade de inserção no mundo da escrita, um ambiente de letramento, tendo em vista um projeto político de investimento em leitura. Evidenciaramse inúmeras dificuldades enfrentadas pelos bibliotecários e assistentes de biblioteca entrevistados, sendo que duas limitações têm uma importância fundamental para se entender um problema que diz respeito não só à Biblioteca Central de Campinas, mas às bibliotecas públicas de um modo geral: o número reduzido de leitores, que não apenas estudantes, e a falta de clareza quanto à função social da biblioteca, por parte dos funcionários que, em sua maioria, não percebem o alcance social e cultural de sua prática, deixando de se preocupar com a formação de leitores e com a ampliação das condições de letramento daqueles que já participam do universo da leitura. Os dados também apontam para a necessidade de que a Secretaria Municipal de Educação, à qual as bibliotecas públicas estão subordinadas, realize projetos no sentido de democratizar a leitura na cidade.

\section{Palavras-chave}

Leitura ; Política de leitura ; Biblioteca pública

\begin{abstract}
The functioning dynamics of the Professor Ernesto Manoel Zink City Library is related to a major problem: investigating whether such public space has been representing not only a possibility of inclusion in the world of writing, but also an environment of literacy for the inhabitants of Campinas - having in mind a political project of investment in reading. Several difficulties have been pointed out by librarians and library assistants, and two limitations are fundamental to the understanding of a problem which concerns not only the Central Library of Campinas, but also all public libraries in Brazil: a reduced number of readers, since most users are students, and the staff's lack of clarity concerning the social function of libraries. Due to the fact that librarians and assistants are not able to realize both the social and cultural reach of their jobs, they do not care about the formation of readers and the enlargement of the conditions of literacy of those who already take part in the universe of reading. Furthermore, the data show that it is essential that the City Department of Education, to which the public libraries in Campinas are subordinate, create projects in order to democratize the reading in the city.
\end{abstract}

Key-words

Reading ; Reading policy ; Public library 


\section{INTRODUÇÃO}

Nas últimas décadas, a linguagem tem sido objeto de estudo de diversas áreas científicas, dentre elas a Línguística, a Sociolingüística e a Psicologia, o que possibilitou uma melhor compreensão teórica a respeito de sua natureza, bem como das relações entre a leitura e a escrita (agora consideradas processos distintos), e entre pensamento $\mathrm{e}$ linguagem.

Além disto, mudanças sócio-políticoeconômicas, advindas do avanço tecnológico, implicaram novas necessidades sociais, exigindo, para a formação de um cidadão, outras habilidades além do domínio do código: passou a ser necessária a compreensão na relação com a escrita.

Deste modo, a concepção clássica de linguagem começou a ser questionada por fundamentar-se no paradigma positivista $^{1}$ e por considerar a linguagem apenas como um instrumento para expressar o pensamento e/ou informar sobre os objetos do mundo; nesta perspectiva clássica, a relação do homem com a linguagem é entendida como dicotômica, sendo a língua considerada como algo acabado que se transmite de geração à geração.

Assim, durante a década de 60, predominaram os preceitos estruturalistas que concebiam a leitura como decodificação do código lingüístico escrito, sendo a escrita mera transcrição fonética; a compreensão exigia a oralização do texto, acreditando-se que o sentido era algo

\footnotetext{
1 In: GROTTA, Ellen C. B. Histórias de relações críticas com a leitura: trajetória de um compromisso político. Projeto de Pesquisa apresentado para exame de qualificação Mestrado, UNICAMP, 1998. (p. 01)
}

estático, pronto e acabado no interior do texto, cabendo ao leitor competente recuperá-lo, através de uma tarefa linear e cumulativa, obtendo-se a compreensão através da soma do significado das frases - estratégia ascendente de leitura (TERZI, 1995).

Nesta perspectiva, a leitura possuía um sentido apenas literal e a compreensão restringia-se ao discurso do autor (o único com poder para fixar o sentido correto); considerado uma fonte de verdades, $\mathrm{o}$ conteúdo deveria ser assimilado e difundido, cabendo ao leitor uma posição passiva diante do texto, devendo apenas assimilar/aceitar as idéias do autor (desconsideravam-se as condições de produção do texto e a constituição ideológica do leitor e conseqüentemente do sentido).

No final da década de 60, psicolingüístas, como Goodman e Smith, revelaram que a leitura processase por estratégias descendentes, ou seja, não se lê separando as palavras em partes, mas tentando perceber o todo, atribuindo-lhe significado e só posteriormente, se necessário, identificando suas partes (GOODMAN, 1996 e SMITH, 1989). Para estes teóricos, o ato de ler envolve a utilização de conhecimentos prévios que permitem a formulação de previsões da leitura e a apreensão de significado, ou seja, a produção de sentidos está centrada na figura do leitor, negando-se, assim, a dialogia e a interação social.

Por sua vez, as elaborações teóricas de BENVENISTE (1991) sobre a subjetividade da linguagem, as de BAKHTIN (1997) sobre a filosofia da linguagem e as de VYGOTSKY (1993) sobre o pensamento e a linguagem permitiram redimensionar a concepção de língua tendo em vista o caráter constitutivo e dialético da mesma, 
sendo tais concepções assumidas neste trabalho como referenciais teóricos.

A linguagem, deste modo, deixa de ser considerada mero instrumento pois " $o s$ sujeitos não 'adquirem' sua língua materna: é nela e por meio dela que ocorre o primeiro despertar da consciência” (BAKHTIN, 1997; p.108), ou seja, "é na linguagem e pela linguagem que o homem se constitui como sujeito" (BENVENISTE, 1991; p. 286)" . Já para VYGOTSKY (1993), "as palavras desempenham um papel central não só no desenvolvimento do pensamento, mas também na evolução histórica da consciência como um todo" (p. 132).

Nesta concepção, a relação do homem com a linguagem é dialética, sendo o primeiro considerado um ser ativo e dinâmico na construção da realidade histórico-social. De acordo com BAKHTIN (1997), a língua não é algo acabado, encontrando-se em um processo evolutivo contínuo, sendo que o homem, ao construir a linguagem, constitui-se por meio dela.

Na dialética da linguagem, a interação verbal é dialógica (todo enunciado só pode ser compreendido no interior da cadeia de enunciados que o antecedem ou sucedem), polifônica (o enunciado não é exclusividade daquele que fala: os enunciados articulam diferentes vozes, pois o falante recria/retoma um discurso a partir de outros pontos de vista) e também polissêmica (o sentido das enunciações é algo dinâmico, variando segundo os contextos que se aplica).

Deste modo, a linguagem é fundamental no desenvolvimento do homem, pois a consciência e o conhecimento do mundo resultam da interação e mediação entre ambos, sendo que o homem não só se constitui pela/na linguagem mas, ao constituir-se, produz e modifica a linguagem, posto ser esta um produto sócio-histórico que somente existe em função do outro, ou seja, na interação verbal.

Para BAKHTIN (1997), "a interação verbal constitui (...) a realidade fundamental da língua”, sendo que o livro (ato de fala impresso) "constitui igualmente um elemento $d a$ comunicação verbal (...), feito para ser apreendido de maneira ativa, para ser estudado a fundo, comentado $e$ criticado"(p. 123).

$\mathrm{Na}$ visão dialética, portanto, os sentidos não estão nem no leitor, nem no autor isoladamente; a leitura é entendida como um processo de produção de sentidos do qual participam autor, texto, leitor e contexto.

De acordo com CHARTIER (1990), os processos de produção de sentido só podem ser compreendidos no cruzamento dos pólos de produção e recepção, ou seja, nas diferentes e contrastantes relações que se estabelecem entre o texto, o suporte que lhe dá sustentação e a maneira como é lido. Desse modo, os sentidos e possibilidades de sua produção seriam construções resultantes do trabalho empreendido pelos escritores (em suas estratégias escriturárias), pelos editores (no processo de fabricação do livro) e pelos leitores (nos modos como eles interagem com os textos que lhes chegam às mãos).

FOUCAMBERT (1994), por sua vez, afirma que "ler significa ser questionado pelo mundo e por si mesmo, significa que certas respostas podem ser encontradas na escrita, significa poder ter acesso a essa escrita, significa construir uma resposta que integra parte das novas informações ao que já se é” (p. 5). 
Chegou-se, assim, a uma nova concepção de leitura e de escrita que passou a basear-se no caráter simbólico da escrita (esta não é mais um fim mas um meio para simbolizar idéias), bem como nos seus usos sociais (a situação discursiva só existe na relação com o outro, não bastando apenas o domínio do código).

Rompeu-se, pois, com a concepção de escrita enquanto espelho da oralidade e um código a ser dominado (habilidades técnicas de ler e escrever), devendo o processo de alfabetização, nesta perspectiva, prever condições para o desenvolvimento das funções cognitivas que permitam pensar sobre o mundo de maneira independente, crítica e criativa, possibilitando o exercício da cidadania.

Segundo SOARES (1998), em virtude da nova realidade social e da nova maneira de compreender a presença da escrita no mundo social, surgiu, na segunda metade dos anos 80 , uma nova palavra no discurso dos especialistas da Educação e das Ciências Lingüísticas: "letramento" (do inglês literacy), que passou a ser utilizada por ela como sinônimo de "alfabetismo" [? Assim, enquanto alfabetizar refere-se a "tornar $o$ indivíduo capaz de ler $e$ escrever"(p.31), letramento "é o estado ou a condição que adquire um grupo social ou um indivíduo como conseqüência de ter-se apropriado da escrita e de suas práticas sociais" (p. 39). Acrescenta SOARES (1998) que:

\footnotetext{
2 Soares, em artigo de 1995, utiliza apenas o termo "alfabetismo"; já em 1996, a autora explica que "embora dicionarizada, alfabetismo não é palavra corrente, e talvez por isso, (...) tenha-se optado por verter a palavra inglesa para o Português, criando a nova palavra letramento"(p.85).É importante salientar, entretanto, que não há um consenso, entre os diversos estudiosos que utilizam o termo letramento, acerca da abrangência de seu signifcado.
}

“...socialmente e culturalmente, a pessoa letrada já não é a mesma que era quando analfabeta ou iletrada, ela passa a ter uma outra condição social e cultural não se trata propriamente de mudar de nível ou de classe social, cultural, mas de mudar seu lugar social, seu modo de viver na sociedade, sua inserção na cultura - sua relação com os outros, com o contexto, com os bens culturais torna-se diferente." (p.37)

SOARES (1995) $)^{\text {B }}$ salienta que letramento, "entendido como um estado ou uma condição, refere-se não a um único comportamento, mas a um conjunto de comportamentos que se caracterizam por sua variedade $e$ complexidade" (p. 8), podendo ser agrupados em duas grandes dimensões: a dimensão individual e a dimensão social.

Com relação à dimensão individual, SOARES (1998) esclarece que o letramento envolve dois processos fundamentalmente distintos - ler e escrever, sendo que as numerosas $\mathrm{e}$ variadas habilidades e conhecimentos que constituem os processos de leitura e de escrita são consideravelmente diferentes.

Dessa forma, segundo ela, "ler estendese desde a habilidade de simplesmente traduzir em sons sílabas isoladas, até habilidades de pensamento cognitivo e metacognitivo" (como, por exemplo, a habilidade de captar o sentido de um texto escrito, de interpretar seqüências de idéias ou acontecimentos, analogias, etc.), sendo que "há ainda o fato de que essas habilidades se aplicam de forma diferenciada a uma enorme diversidade de materiais escritos"(p.8) (dentre eles,

\footnotetext{
${ }^{3}$ Embora no artigo de 1995 Soares utilize mais o termo alfabetismo, optou-se nesse trabalho pelo uso da palavra letramento, pois atualmente é o mais empregado.
} 
literatura, material didático, jornais, anúncios, etc.)

Por outro lado, escrever, segundo SOARES (1995), "engloba desde a habilidade de traduzir fonemas em grafemas, até habilidades cognitivas $e$ metacognitivas" (como, por exemplo, habilidades motoras, ortografia, uso adequado da pontuação, habilidade de organizar as idéias no texto, etc.), sendo que, assim como com relação à leitura, as habilidades e conhecimentos de escrita "devem ser utilizadas diferencialmente para produzir uma diversidade de materiais escritos"(p. 9), envolvendo desde a simples assinatura do próprio nome até a produção de uma tese, por exemplo.

Do ponto de vista de sua dimensão social, o letramento "não se limita pura e simplesmente à posse individual de habilidades e conhecimentos; implica também, e talvez principalmente, um conjunto de práticas sociais associadas com a leitura e a escrita, efetivamente exercidas pelas pessoas em um contexto social específico" (SOARES, 1995 : p. 10).

Afirma SOARES(1995) que há pontos de vista conflitantes sobre esta dimensão social do letramento, os quais podem ser resumidos em duas tendências: uma tendência progessista ou "liberal" e uma tendência radical, "revolucionária".

A tendência "liberal" baseia-se no valor pragmático e adaptativo do letramento, ou seja, na necessidade e importância deste " para um funcionamento efetivo na sociedade, tal como ela é"(alfabetismo funcional); já a tendência "revolucionária", baseia-se no poder revolucionário do letramento, isto é, "em sua força potencial para transformar as relações e práticas sociais consideradas indesejáveis ou injustas"(SOARES, 1995: p. 12).

Portanto, remetendo-se a Paulo Freire, SOARES (1995) afirma que o letramento "pode ser um instrumento tanto para a libertação quanto para a domesticação do homem, dependendo do contexto ideológico em que ocorre"(p. 12).

SOARES (1995) conclui que "uma e outra versões levam à relatividade do conceito de letramento: "se as práticas sociais que envolvem a língua escrita dependem da natureza e estrutura da sociedade, bem como do projeto que determinado grupo político assume, essas práticas variam no tempo e no espaço (...) sendo "impossível formular um único conceito..." (p.12).

Em decorrência disto, SOARES (1995) afirma que o estudo do letramento "tem que ser multidisciplinar, e que só a contribuição de diferentes ciências poderá conduzir a um entendimento claro desse fenômeno"(p. 14).

Dentre as perspectivas de análise propostas por SOARES (1995), a que melhor condiz com o propósito deste trabalho é a perspectiva política, "que analisa as condições de possiblidade de programas de promoção do [letramento], que determina objetivos e metas do [letramento], que analisa ideologias subjacentes a programas $e$ campanhas de alfabetização, que estabelece e promove circuitos de difusão, distribuição e circulação da escrita..." (SOARES, 1995: p. 14).

Como anteriormente afirmado, o nível de letramento da população de um país está estritamente ligado a uma questão mais ampla de política social, uma vez que, segundo SOARES (1998), implica que haja "escolarização real e efetiva da população", e ainda, que haja 
"disponibilidade de material de leitura" (p. 58), o que possibilitaria não apenas dar condições para ler e escrever, mas também "condições para que os alfabetizados passassem a ficar imersos em um ambiente de letramento" (p. 58), onde as pessoas tivessem acesso a livros, revistas, jornais, livrarias e bibliotecas, possibilitando à leitura e escrita tornarem-se uma necessidade e uma forma de lazer para elas.

Neste sentido, a questão colocada por SILVA (1997) é fundamental: "De que adianta 'saber ler' se os objetos de leitura (...) não são colocados à disposição do indivíduo? (...) De que adianta 'saber ler' se não existe um projeto social orientado para despertar a consciência crítica através da leitura? Estas perguntas reclamam que outras condições, de ordem sócio-cultural e econômica, são necessárias para que a prática da leitura seja efetivamente exercida." (p.47)

FOUCAMBERT (1994), ao abordar questões acerca da leitura na França, afirma que "não existe um só campo em que a verdadeira prática da democracia não passe pelo acesso do maior número de pessoas à escrita. Não há partilha possivel do poder sem a partilha do acesso à escrita." (p. 25)

Segundo ele, soluções para os casos de não-leitura "só ganharão sentido num projeto global que se precisa definir previamente"(p. 26), sendo necessário encontrar as condições sociais e comunitárias que surtirão efeitos semelhantes àqueles propiciados pelas condições familiares (de classe social).

FOUCAMBERT (1994) argumenta que a escola pode alfabetizar, mas não garante a formação do leitor, o que exige "tempo de vida dentro de um meio educativo que já confere ao interessado um status de leitor"(p. 23). Para isto, segundo ele, é necessário desescolarizar a leitura, no sentido de que medidas paliativas contra o analfabetismo (geralmente referentes aos métodos de alfabetização) devem ser substituídas por um processo de leiturização e formação permanente do leitor, a ser assumido por todas as instâncias educativas, o que consiste numa opção política global que implica em transformações no conjunto de relações sociais, "tanto no sistema produtivo como na vida das coletividades, nos meios de informação, na partilha política, no sistema educativo e na família"(p. 26).

Pela forma como o aprendizado da leitura vem se concretizando, FOUCAMBERT (1994) acredita que iletrados e não-leitores têm vivenciado um processo de exclusão das redes de comunicação escrita, não sendo considerados destinatários dos escritos presentes em seu ambiente, deixando de se beneficiarem de uma real relação com a escrita, ou seja, não têm o estatuto de leitores.

De acordo com FOUCAMBERT (1994), esta exclusão não reside numa carência de técnicas, mas "na ausência de motivos para dotar-se com essas técnicas" (p. 47); para ele, a ampliação do poder é que "justifica as atuais razões de ir ao encontro da escrita", sendo que "as condições de poder dependem, primeiramente, de estruturas que ultrapassam amplamente o âmbito da sala de aula" (p.34), devendo a escola organizar-se em torno de "serviços gerais" (no caso da França, o autor cita as Bibliotecas- Centros-deDocumentação, a oficina "jornal" ou "rádio" e os projetos - produções reais, destinadas ao meio interno e externo da escola).

FOUCAULT (1991), por sua vez, ao analisar a história da violência nas prisões, afirma que talvez seja 
necessário "renunciar a toda uma tradição que deixa imaginar que só pode haver saber onde as relações de poder estão suspensas e que o saber só pode desenvolver-se fora de suas injunções, suas exigências, seus interesses", admintindo que "o poder produz saber (...), que poder e saber estão diretamente implicados; que não há relação de poder sem constituição correlata de um campo de saber, nem saber que não suponha e não constitua ao mesmo tempo relações de poder.”(pp.29-30)

Esta relação poder-saber, apontada por FOUCAULT (1991), parece corroborar o que FOUCAMBERT (1994) afirma com relação à ampliação do poder através da inserção do indivíduo no universo da palavra escrita, razão principal que deve impulsionar iletrados e não-leitores a vivenciarem o estatuto de leitor.

Considera-se, assim, no presente trabalho, a leitura como uma atividade lingüística constitutiva do sujeito, ao mesmo tempo que constituída/ produzida por ele, tendo em vista ainda que "o domínio da língua tem estreita relação com a possibilidade de plena participação social", sendo direito inalienável de todos "o acesso aos saberes lingüísticos necessários para o exercício da cidadania"(BRASIL, 1997: p. 23).

Assim como FOUCAMBERT (1994), acredita-se que "a responsabilidade por uma política de leitura deve ser exercida pelas coletividades locais (...), num duplo movimento de descentralização e autogestão, [coordenando] todos os atores e todos os locais, bem como avanç[ando] rumo à criação das condições sociais que garantem o direito à leitura para todos."(p.15).
A questão da inserção do sujeito nas práticas sociais de leitura ${ }^{4}$, ou seja, seu nível de letramento, decorre, portanto, de uma política social mais ampla, extrapolando o campo das ações individuais. É importante salientar, conforme afirma Brito (1998) que:

"Se queremos incentivar a leitura
efetivamente, como um bem
público, como uma marca de
cidadania, temos de abandonar
visões ingênuas e fantasiosas de
leitura e investir num movimento
pelo direito de poder ler. O
excluído de fato da leitura não éo
sujeito que sabe ler e não gosta
de romance, mas o sujeito que, no
Brasil de hoje, não tem terra, não
tem emprego, não tem
habitação." (p.2)

Para BRITO (1998), escolas e bibliotecas públicas são, sem dúvida, as duas instâncias mais diretamente ligadas à formação do leitor e ao acesso aos textos. Assim, uma pesquisa que pretenda investigar condições de letramento deve, inevitavelmente, eleger o espaço escolar e/ou das bibliotecas públicas como locais privilegiados de formação do leitor e do acesso aos textos.

Tendo em vista a problemática das condições de letramento de uma forma mais ampla (e não apenas em relação às escolas), optou-se neste trabalho pela análise do funcionamento de uma das quatro bibliotecas públicas de Campinas. Espera-se que, ao término dessa pesquisa, consiga-se discutir pelo menos alguns dos aspectos propostos por SILVA (1995) com relação às bibliotecas brasileiras:

\footnotetext{
${ }^{4}$ Apesar da ênfase que damos à leitura neste projeto, entendemos que tanto ela como a escrita "são práticas complementares, fortemente relacionadas, que se modificam mutuamente no processo de letramento" (PCN, p. 52).
} 
"A quem as bibliotecas brasileiras estão servindo? Ao povo ou a uma elite de privilegiados? Quais os esforços que vêm sendo feitos pelas bibliotecas no sentido de democratizar os seus espaços e de popularizar os seus acervos? Quem efetivamente freqüenta as bibliotecas neste país? Qual a influência exercida pelas bibliotecas, traduzida em ação concreta, na luta do povo brasileiro em favor da conquista da liberdade e da democracia?" (p. 96)

\section{MÉTODO}

\section{A instituição}

Em seu site, na Internet, a Secretaria Municipal de Educação esclarece que a Biblioteca Municipal "Prof. Ernesto Manoel Zink", juntamente com as outras três bibliotecas municipais (por ela coordenadas), tem os seguintes objetivos: "preservar e socializar o saber histórico, promovendo a pesquisa, a leitura de lazer, de estudo, de informação $e$ de atividades culturais"; "auxiliar o aluno a adquirir um mecanismo fundamental $d a$ sociedade informativa: o hábito da pesquisa".

Tendo sido fundada em 15.11.1946, a Biblioteca Central (como é popularmente conhecida) conta com o seguinte acervo: 8.972 obras no setor permanente e 20.430 obras no setor circulante.

Este acervo subdivide-se em: 1586 obras infantis; 1550 obras rara/semiraras (355 obras do acervo Magalhães Teixeira e 1538 obras de autores campineiros); periódicos; hemeroteca (recortes de jornais e revistas); mapoteca; braile (2500 obras/100 livros falados); vídeos (64 fitas educativas); "espaço biXo" (apostilas de cursinhos, etc.) e o "caixote de letras" (acervo de 60 livros de literatura nacional e estrangeira rodiziando 60 dias em instituições como: escolas, hospitais, postos de saúde, igrejas, etc.).

A biblioteca desenvolve também atividades culturais que "visam ampliar e diversificar os usuários..."; a Secretaria Municipal de Educação esclarece, em seu site, que "sendo a Biblioteca Pública o Centro de Referência e Cultura da Comunidade não pode deixar de contemplar as atividades musicais dentro de [seus] projetos." A Biblioteca Central promove ainda exposições e concursos literários.

A Secretaria Municipal de Educação tem os seguintes projetos em estudo: "Conversa com escritores campineiros", "Arte concreta na biblioteca", "Mala da Leitura" (em hospitais), "Leitura em terminais de ônibus".

Por fim, ressalta-se a participação da Biblioteca no "Programa Nacional de Incentivo à Leitura" (PROLER), da Fundação Biblioteca Nacional, que tem como finalidade "incentivar e promover programas de ação social cujo objetivo seja a criação de espaços de leitura elou de práticas leitoras".

\section{Sujeitos}

Os sujeitos da pesquisa foram seis bibliotecários e quatro assistentes de biblioteca, que atuam na Biblioteca Central em três de seus setores: permanente, circulante e braile.

O primeiro contacto foi com a coordenadora das bibliotecas públicas de Campinas; na ocasião, foi realizada uma entrevista informal com a coordenadora com o objetivo de se conhecer melhor o funcionamento das bibliotecas públicas de Campinas, pois 
ainda não estava definido qual seria, especificamente, o objeto da presente pesquisa (sabia-se apenas que o estudo envolveria a questão das políticas de leitura na cidade, restringindo-se a análise dessa problemática ao espaço das bibliotecas públicas).

Após essa entrevista, delimitou-se como universo da pesquisa a Biblioteca Central por ser mais representativa da dinâmica de funcionamento do serviço, pois as outras três bibliotecas atendem a um público mais restrito por estarem localizadas em bairros/subdistritos de Campinas, sendo que uma delas é direcionada a um público infantil.

Assim, por sua localização (área central da cidade) e por atender a um público supostamente mais variado, optou-se pela análise do funcionamento da Biblioteca Central. Para tanto, a coordenadora muito colaborou no sentido de divulgar o trabalho a ser realizado, bem como propiciando o agendamento das entrevistas no próprio horário de trabalho dos bibliotecários e assistentes de biblioteca, incentivandoos a colaborar com a pesquisa. A caracterização dos sujeitos 5 entrevistados (seis bibliotecários e quatro assistentes de biblioteca), é resumidamente descrita a seguir.

Quanto aos bibliotecários, todos possuem nível universitário, tendo cursado Biblioteconomia; prestaram concurso público para ingressar na Biblioteca Municipal (a maioria iniciou suas atividades em 1997, sendo que apenas uma bibliotecária ingressou em 1991). Realizam atividades distintas: um bibliotecário organiza o setor de periódicos (de revistas), uma bibliotecária cuida da hemeroteca (de recortes de jornal), duas outras

\footnotetext{
${ }^{5}$ Havia mais uma bibliotecária no quadro de funcionários, mas ela se encontrava de licença gestante.
}

respondem pelo processamento técnico, sendo que uma delas é supervisora deste setor.

Uma das bibliotecárias foi convidada, em 1996, pelo Secretário da Educação, a assumir a coordenação das quatro bibliotecas públicas municipais de Campinas (é a única que deu continuidade à sua formação, tendo terminado recentemente o Mestrado na área de Biblioteconomia, pretendendo prosseguir com o Doutorado).

Quanto aos quatro assistentes de biblioteca, dois deles ingressaram em 1998, através de concurso, atuando no balcão de atendimento do setor permanente; os demais foram contratados no final da década de 80, sendo que um deles foi convidado a trabalhar no setor braile por sua experiência em outra entidade; a outra assistente de biblioteca faz a parte de classificação da hemeroteca e, provisoriamente, também está encarregada do xerox .

Quanto ao nível de escolaridade, todos os assistentes de biblioteca concluíram o nível médio, sendo que dois deles cursam, atualmente, Direito e Serviço Social. Os outros dois demonstram interesse em continuar sua formação em nível superior, porém descartam o curso de Biblioteconomia (segundo um deles, devido ao fator econômico).

\section{Dados coletados}

\section{Natureza dos dados}

$\mathrm{Na}$ presente pesquisa, foram coletados três conjuntos de dados:
a) Relatos verbais de todos os funcionários;
b) Informações sobre os usuários;
c) Informações sobre retirada de livros do setor circulante.


Caracteriza-se, portanto, como uma pesquisa qualitativa, cujas características podem ser encontradas em BOGDAN e BIKLEN (1991).

\section{Procedimentos da coleta de dados}

\section{a) Relatos verbais:}

O caráter desta pesquisa impôs a adoção de procedimentos de coleta de dados que incluíram a entrevista semidiretiva, de acordo com LÜDKE e ANDRÉ (1986).

A entrevista semi-diretiva, nesta pesquisa, permitiu que o entrevistado discorresse livremente sobre o tema proposto, sendo apresentadas perguntas de acordo com o seguinte roteiro:

1. Como chegou a esta função de bibliotecário/assistente de biblioteca?

2. Qual é sua formação acadêmica (nível de escolaridade)?

3. Descreva o trabalho que você realiza nesta biblioteca.

4. Você gosta do que faz?

5. Qual a função do bibliotecário em nossa sociedade?

6. Caracterize as pessoas que frequientam esta biblioteca.

7. O que estas pessoas esperam desta biblioteca?

8. Os leitores saem satisfeitos daqui?

9. Qual a função da leitura em nossa sociedade?

10. Você também costuma emprestar livros?

11. Como avalia o serviço prestado pela biblioteca pública de Campinas?

12. A Prefeitura Municipal de Campinas investe em políticas de leitura?

As entrevistas foram agendadas respeitando-se a possibilidade de horário de cada um (durante o próprio expediente) e gravadas com a autorização prévia de todos os sujeitos. Após a gravação, procedeu-se à transcrição integral de todos os relatos verbais. A partir da leitura desses dados, foram criados conjuntos e subconjuntos temáticos que permitiram uma melhor organização e posterior análise do material.

\section{b) Informações sobre os usuários}

Com o objetivo de traçar um perfil preliminar dos usuários da Biblioteca Central, analisou-se o único material existente na biblioteca sobre eles: as fichas cadastrais daqueles usuários que fizeram carteirinha para poder realizar o empréstimo de livros do setor circulante. Nessa ficha, deveriam constar os seguintes dados: nome completo do usuário, número e data da inscrição, assinatura, endereço e telefone de sua residência, profissão, lugar em que trabalha e telefone, identidade e data de nascimento.

Como o setor circulante ainda não está informatizado, todas as fichas foram preenchidas à mão e arquivadas por ordem alfabética. Cabe ressaltar, conforme esclarecimentos da bibliotecária responsável pelo setor circulante, que houve um recadastramento geral em 1996; assim, as fichas cadastrais existentes no arquivo no momento da pesquisa eram referentes ao período de 1996 a 1998 (perfazendo a quantia de, aproximadamente, 8500 leitores), além daquelas referentes ao ano de 1999, dos novos cadastrados, sendo que, anualmente, todos os usuários devem atualizar seu endereço.

Dentre as informações solicitadas na ficha cadastral, entretanto, nem todas puderam ser recuperadas devido ao preenchimento incompleto que, segundo a bibliotecária, deve-se à própria falta de espaço na ficha; assim, selecionaram-se dois itens considerados 
relevantes para a pesquisa: profissão e idade do usuário, tendo-se desconsiderado as fichas cadastrais que não apresentassem esses dados.

Após realizar a leitura e seleção das fichas cadastrais que preenchiam as condições preestabelecidas, organizaram-se os dados coletados da seguinte maneira:

quanto à profissão: utilizando-se o quadro de ocupações profissionais presente no Manual do Candidato do Vestibular da UNICAMP, organizaramse as profissões dos usuários em oito categorias

Categoria 1: altos cargos públicos e administrativos, proprietários de grandes empresas e assemelhados.

Categoria 2: profissionais liberais, cargos de gerência ou direção, proprietários de empresas de tamanho médio e assemelhados.

Categoria 3: posições mais baixas de supervisão ou inspeção de ocupações não-manuais, proprietários de pequenas empresas comerciais, industriais, agropecuárias, etc.

Categoria 4: ocupações não-manuais de rotina e assemelhadas.

Categoria 5: supervisão de trabalho manual e ocupações assemelhadas.

Categoria 6: ocupações manuais especializadas e assemelhadas.

Categoria 7: ocupações manuais não especializadas.

Categoria 8: ocupações do lar.

É necessário esclarecer que, no caso da profissão de professor, o manual remete a duas categorias: a 3, para professor secundário, e a 4, para professor primário. Nos casos em que o usuário registrava, na ficha cadastral, que sua

${ }^{6}$ In: Vestibular UNICAMP 2000 - Manual do Candidato. Publicação da Coordenação Executiva dos Vestibulares. Campinas, SP : Ed. Ave Maria, 1999. profissão era "professor", sem especificar o nível, optou-se por enquadrá-lo na categoria 4, uma vez que, na maior parte das fichas cadastrais em que apareceu a profissão de professor com o nível correspondente, havia uma predominância do nível fundamental. Além disso, a leitura das fichas cadastrais revelou que muitos usuários registram como profissão sua condição de "estudante", o que não consta do quadro de ocupações profissionais utilizado. Assim, decidiuse pela utilização de mais uma "categoria", além das oito já existentes: a Categoria 9 - estudantes (raramente há informações sobre o nível, por isso desconsideramos esse dado).

quanto à idade: após levantamento da data de nascimento dos usuários, organizaram-se os dados dos mesmos por faixa etária.

\section{c) Informações sobre retirada de livros do setor circulante:}

Para complementar o perfil do usuário da Biblioteca Central, buscou-se identificar que tipo de leitura ele realiza, ou seja, que tipo de livros e assuntos são mais procurados e retirados. No entanto, como o setor circulante ainda não se encontra informatizado, foi impossível conseguir este tipo de dado.

Por outro lado, a bibliotecária do setor circulante criou uma planilha onde registra, dia a dia (tanto no período da manhã como no da tarde), a quantidade de livros retirados, tendo em vista as seguintes classes, identificadas pelos seguintes códigos:

- 000: Obras Gerais

- 100: Filosofia

- 200: Religião

- 300: Ciências Sociais

- 400: Linguiística/Línguas

- 500: Ciências Puras

- 600: Medicina/Adm./Eng. 
- 700: Artes

- 800: Literatura

- 900: História/Geografia

- BIOGR.: Biografia

- AP./DESC.: Apostilas/Material

Descartável

- 028.5: Literatura infanto-juvenil

- VESTIB.: livros exigidos pelos vestibulares

Ao final de cada mês, a bibliotecária totaliza todas as classes de livros, registrando também o número de cadastros feitos (relativo à carteirinha de novos sócios). Com base nessas planilhas de controle de retirada, gentilmente cedidas pela bibliotecária, foi possível fazer um levantamento dos livros emprestados pelos usuários da biblioteca durante o período que vai de março de 1998 a março de 1999 (não havendo registro referente à janeiro de 1999, pois a Biblioteca Central permaneceu fechada).

\section{RESULTADOS}

\section{Dados das entrevistas}

Após a transcrição dos relatos verbais, os mesmos foram organizados em conjuntos e subconjuntos temáticos, os quais são apresentados na seqüência.

\section{ROTINA DE TRABALHO}

Este conjunto temático contém os relatos verbais que descrevem o trabalho realizado diariamente pelos sujeitos na biblioteca; subdvidiu-se em dois subconjuntos, tendo em vista as diferentes funções dos sujeitos entrevistados (bibliotecários e assistentes de biblioteca).

Rotina de bibliotecários

Neste subconjunto, os bibliotecários relatam sua rotina de trabalho na
Biblioteca Central. Como os sujeitos, apesar de terem a mesma função, atuam em setores e cargos diferenciados, procurou-se detectar aspectos comuns presentes em seus relatos.

Um primeiro ponto salientado foi o fato de a maioria dos sujeitos ter passado e ainda passar, por vários setores da biblioteca. Isso ocorre(u) tanto devido a um momento inicial na carreira, quando não havia um cargo específico a ser preenchido, quanto a uma situação de acúmulo de função, em virtude da falta de funcionários, havendo um esquema de revezamento para suprir essa deficiência.

Outro aspecto presente nos relatos verbais dos bibliotecários foi a importância que os sujeitos atribuem ao contacto com o público, principalmete para aqueles que desempenham funções mais internas relativas à organização do acervo, por ser uma forma de conhecer melhor as prioridades e necessidades do usuário.

Um dos sujeitos salienta uma questão que também é, de certo modo, abordada por outros sujeitos, ainda que em outros subconjuntos: uma espécie de divisão existente na área de Biblioteconomia, havendo uma área mais ligada à administração/organização e outra relacionada à parte cultural, prevalecendo uma visão de que a primeira envolve um trabalho mais "mecânico", sendo por isso mesmo desprestigiada.

\section{Rotina de assistentes}

O trabalho específico do assistente de biblioteca caracteriza-se por ser mais prático, principalmente no caso dos sujeitos que foram contratados recentemente e que trabalham no balcão de atendimento do setor permanente. 
Por outro lado, assistentes que têm mais tempo de serviço ou que trabalham em um setor específico, como o da biblioteca braile, desempenham tarefas diversas, não ficando apenas com a atividade de atendimento (o assistente desse último setor, por exemplo, também procede à organização do acervo, controla a entrada e saída do material, a chegada de livros novos e realiza o tombamento e o fichamento dos livros).

\section{REALIZAÇÃO PROFISSIONAL}

Este conjunto temático inclui os relatos verbais que descrevem a motivação dos sujeitos no desempenho de suas funções. Todos os sujeitos afirmam gostar do que fazem. Apesar disso, muitos apontaram aspectos que lhes desagradam no desempenho de suas funções ou, de um modo mais geral, ligados à área de Biblioteconomia.

As ressalvas feitas pelos sujeitos remetem à falta de afinidade com a área mais técnica da Biblioteconomia (há uma preferência pelo desenvolvimento de atividades mais culturais, de incentivo à leitura, e pela área de pesquisa), às dificuldades financeiras de se trabalhar na área de bibliotecas públicas, à inexistência da função de bibliotecário de referência (o que permitiria realizar um trabalho de orientação à pesquisa), à impossibilidade de auxiliar os estudantes no setor permanente devido à grande demanda e enormes filas; tais aspectos que tornam estafante o dia-adia de quem atua nesse setor, em detrimento do que acontece no setor circulante (considerado por alguns mais interessante).

\section{USUÁRIOS}

Os relatos verbais contidos neste conjunto temático estão relacionados com o usuário do serviço da Biblioteca Central, tendo em vista diferentes aspectos, o que levou à subdivisão deste em cinco subconjuntos, descritos a seguir.

Perfil do usuário

Neste subconjunto, procurou-se agrupar os relatos verbais que evidenciassem como o usuário da Biblioteca Central (independentemente do setor) é visto pelos sujeitos entrevistados.

Ainda que alguns dos sujeitos afirmem que o perfil do usuário da biblioteca é amplo, não sendo possível falar em um perfil único, a maior parte dos relatos verbais evidencia que o tipo de público que freqüenta a Biblioteca Central é constituído, em sua maioria, por estudantes de $1^{\circ}$ e $2^{\circ}$ graus (principalmente de $5^{\mathrm{a}}$ série ao $3^{\mathrm{o}}$ colegial), de escolas públicas municipais e estaduais (raramente são de escolas particulares) que, geralmente, trabalham de dia e estudam à noite, residem na periferia e utilizam a biblioteca quase que exclusivamente para a realização de pesquisa escolar.

A predominância desse tipo de usuário é associada a algumas características e problemas da Biblioteca Central: toda a atenção converge para o setor permanente da biblioteca, o qual se torna prioritário (o que se evidencia pelo fato de mais pessoas trabalharem no balcão de atendimento, dos livros desse setor serem consertados em primeiro lugar...).

O problema da deterioração do acervo também é mencionado por alguns sujeitos, que o atribuem a fatores como o desespero daqueles usuários que necessitam entregar sua pesquisa escolar no prazo estabelecido e não têm tempo para pesquisar porque trabalham e não podem aguardar o atendimento 
nas longas filas do balcão ou do xerox do setor permanente.

Um outro motivo apontado é a falta de conscientização dos usuários que não percebem que a biblioteca é um espaço coletivo (o que, para um dos sujeitos, reflete a degradação do sistema de ensino e da educação de um modo geral), o que o leva a ter um pensamento individualista e a deteriorar o acervo, sem ter noção de que ele, como usuário, é a maior vítima.

Por outro lado, além deste público majoritário, existe uma comunidade leitora que utiliza a Biblioteca Central sem ter como objetivo a realização de pesquisa escolar: são os leitores de jornal (muitas vezes à procura de emprego), donas de casa que buscam romances, além das crianças e universitários (em menor número), que utilizam o setor circulante.

Com relação aos universitários, um dos sujeitos acredita que o universitário bem informado nunca vai à biblioteca pública porque imagina que não vai encontrar o que procura.

A comunidade leitora, entretanto, parece não manter com a biblioteca a mesma relação de antigamente pois, conforme relatou a coordenadora, há pessoas que vêm freqüentado a biblioteca há vários anos; segundo ela, antigamente, esse espaço tinha mais função em suas vidas, desde a infância até a formação superior (alguns não compravam livros porque dispunham do acervo da biblioteca).

Acredita-se que a predominância de um público que se constitui, basicamente, de estudantes não tem a ver com o acervo da Biblioteca Central, devendose à defasagem de bibliotecas escolares, o que leva a instituição a funcionar como uma biblioteca escolar coadjuvante.

Ao mesmo tempo, parece haver um perfil "ideal" do usuário, sendo que um dos sujeitos afirma que a biblioteca pública deveria ser utilizada por pessoas que desejam exercitar sua leitura, que procuram informação para sua vida. Acredita-se, entretanto, que uma transformação no perfil do usuário da Biblioteca Central só ocorrerá gradualmente, tendo a escola um papel fundamental nesse processo.

Diferenças entre os usuários dos setores circulante, permanente e braile

Nesse subconjunto, os sujeitos relatam as especificidades dos usuários de cada um desses setores da Biblioteca Central.

\section{- Setor circulante}

De um modo geral, os usuários desse setor são descritos como um público mais restrito, que acaba estabelecendo um contacto mais próximo com os funcionários; têm um nível sócioeconômico um pouco melhor, mais escolaridade, pertencem a uma faixa etária mais elevada, vão à biblioteca em busca de uma leitura de lazer, de entretenimento, mais literária.

Considerado um setor mais "nobre", conta ainda com um número considerável de estudantes que vêm de outras cidades para fazer cursinho prévestibular em Campinas, os quais "disputam" os poucos exemplares disponíveis dos livros de literatura indicados para os exames vestibulares, como os da UNICAMP e da FUVEST.

Outros segmentos menores de público do setor circulante são os estudantes que necessitam realizar a pesquisa escolar que, por não disporem de tempo, optam pelo empréstimo de 
material (quando isso é possível); os leitores infantis (que costumam utilizar mais a biblioteca da própria escola, quando ela existe) e também pessoas que procuram livros mais técnicos relacionados à sua profissão (eletricidade, mecânica, etc.)

Os relatos de alguns sujeitos descrevem o setor circulante como sendo um espaço em que as pessoas têm mais expectativas, porque a leitura é um hobby, um prazer e não uma coisa imposta, sendo que o usuário "ideal" é aquele que procura pela biblioteca como um espaço a que tem direito enquanto cidadão que paga imposto.

\section{- Setor permanente}

Em oposição ao setor circulante, o permanente é descrito pelos sujeitos como uma espécie de "cavalo de tróia", apresentando maiores dificuldades em virtude da grande demanda por pesquisa escolar. O perfil dos usuários desse setor foi assim definido pelos sujeitos: em sua maioria, são alunos de escolas públicas, de $1^{\circ}$ e $2^{\circ}$ graus; muitos vêm da periferia da cidade por não terem opção na escola e no bairro; a maior parte tem pouco domínio da escrita e chega sem saber exatamente o que quer; têm pouca condição de estudo, dificilmente questionam muito. Há pessoas que têm dificuldades financeiras até para chegar à biblioteca.

Contrapondo-se ao setor circulante, o setor permanente raramente é freqüentado por interesse próprio, não demonstrando o usuário grandes expectativas, preocupado apenas em cumprir uma tarefa solicitada pelo professor. Assim, prevalece uma maior rotatividade dos usuários nesse setor, que também costuma ser freqüentado por pessoas de cidades vizinhas, como Sumaré e Valinhos, conforme relataram os sujeitos entrevistados.
Apesar dessas dificuldades, ou justamente por elas, o setor permanente tem sido visto como prioritário. Todos os esforços são para que ele funcione, o que inclui a abertura da biblioteca aos sábados e a existência de uma máquina de xerox, apesar da lei de direito autoral, tudo para dar conta da grande demanda por pesquisa.

\section{- Setor braile}

O funcionamento da biblioteca braile é muito semelhante ao da biblioteca comum; como a maior parte do material pode ser retirada por empréstimo (com exceção de dicionários), ela se constitui, basicamente, por um acervo circulante; por serem em número reduzido, os usuários do setor braile mantém uma relação mais próxima com os funcionários. Há, entretanto, uma especificidade que caracteriza esse setor: é um espaço socializante, onde as pessoas buscam informação de um modo geral e não apenas livros. Funciona como um ponto de encontro, onde os usuários comparecem para buscar informação, para bater papo ou para ter contacto com os eventos que ocorrem na cidade.

Por outro lado, a questão da pesquisa escolar, em contraposição à leitura "prazerosa", também está presente nesse setor pois, conforme relatou o assistente de biblioteca por ele responsável, dentre as cinqüenta pessoas que o freqüentam, cerca de dez têm o hábito de ler.

Em termos de pesquisa escolar, o acervo existente no setor braile consegue atender principalmente a demanda do ensino fundamental, sendo que a maior parte dos alunos que procuram o setor são de escolas da rede pública. 
Imagem que o público tem da biblioteca

Nesse subconjunto, procura-se destacar os relatos verbais que descrevem a imagem que o usuário tem da Biblioteca Central, na perspectiva dos sujeitos entrevistados.

Ainda que um dos sujeitos tenha apontado um aspecto que remete a uma imagem positiva da biblioteca junto aos usuários, por ser um local onde é muito mais fácil encontrar uma informação, comparativamente a outros lugares onde o acesso é mais restrito, a maioria dos sujeitos acredita que as pessoas têm uma visão negativa da Biblioteca Central (e até das bibliotecas de um modo geral), que costuma ser vista como uma coisa rançosa, antiga, que cheira a mofo.

De acordo com um dos sujeitos entrevistados, há pessoas que consideram a biblioteca um mal necessário, um local onde têm que passar e perder uma tarde, quando poderiam estar no shopping com a namorada ou com os amigos. Já os universitários não têm interesse pela biblioteca porque, para este público, segundo um dos entrevistados, o acervo é deficiente.

A própria mídia, conforme afirma um dos sujeitos, faz com que a população acabe por ter uma idéia errônea e não utilize, de uma forma mais ampla, esse espaço público, o que se comprovou quando da publicação de um artigo sobre a Biblioteca Central, que saiu com a seguinte manchete: "Biblioteca Pública - bolor e pó", em chamada de primeira página.

Assim, conforme afirmou a coordenadora das bibliotecas públicas de Campinas, a visão negativa do usuário, mantida ou reforçada pela mídia, leva a um desconhecimento dos serviços oferecidos, havendo pessoas que, por seu nível de letramento, se consideram praticamente analfabetas e, em razão disso, afastam-se de um espaço que, para elas, é praticamente "sagrado". Por outro lado, pessoas cujo nível de letramento é maior encaram a biblioteca pública como uma espécie de "museu", com um acervo ultrapassado, não havendo, portanto, interesse em consultá-lo.

Essa situação, conforme relatou um dos sujeitos, acaba por fazer persistir a presença quase que exclusiva de estudantes na Biblioteca Central, interessados apenas em realizar sua pesquisa escolar e ir embora, considerando a biblioteca necessária apenas durante o período letivo.

A "metodologia" de pesquisa do usuário e o ensino nas escolas

Nesse subconjunto, os sujeitos entrevistados avaliam o ensino atual em função da forma como o usuário da Biblioteca Central procede ao realizar sua pesquisa.

De um modo geral, as pessoas que vão fazer pesquisa, independentemente da idade e do nível de escolaridade, são descritas como sendo muito despreparadas e desorientadas, pois chegam à biblioteca sem saber ao certo o que procuram (o tema da pesquisa), raramente dispõem de uma bibliografia e, como apresentam dificuldade até mesmo para entender o que lêem, a utilização de índices e sumários como forma de orientação torna-se totalmente inviável.

As condições de trabalho no setor permanente da Biblioteca Central, por outro lado, são marcadas pela grande demanda de usuários e pelas longas filas no xerox, o que inviabiliza um trabalho de orientação à pesquisa. A 
maioria dos sujeitos afirma que, apesar da função do assistente ser o fornecimento do material, ele acaba tendo que dar tudo muito "mastigado", procurando o tema a ser pesquisado, abrindo na página, não sendo possível orientar o usuário de modo que este torne-se mais autônomo.

Outros sujeitos salientam que o procedimento dos usuários, ao realizarem sua pesquisa escolar, reflete o ensino no país e a falta de proximidade entre escola e biblioteca e entre bibliotecários e professores (que, de um modo geral, em sua opinião, solicitam a pesquisa apenas para ajudar na média do aluno). Ainda que sem saber como modificar a forma como os usuários realizam sua pesquisa, os sujeitos entrevistados acreditam que o ideal seria que os professores arranjassem outra maneira de avaliar o aluno e que este passasse a pesquisar por curiosidade, para fazer um trabalho bem feito.

\section{O usuário e a leitura}

Nesse subconjunto, ao descrever suas conjecturas sobre qual é a função da leitura para os usuários, os sujeitos entrevistados afirmam que as pessoas que utilizam a biblioteca não relacionam a leitura à questão da cidadania, sendo mais uma atividade imposta pelo professor.

Os relatos verbais mencionam ainda dois aspectos relativos à questão da leitura realizada pelos usuários: a falta de hábito/gosto e a falta de acesso. Com relação ao primeiro item, acredita-se que as pessoas, de um modo geral, não têm o hábito de ler (com exceção das pessoas mais idosas). $\mathrm{O}$ mais preocupante, entretanto, segundo a coordenadora, é a falta de acesso à leitura, problema que atinge segmentos sociais cuja situação sócio-econômica é precária, sendo que muita gente desconhece que é possível retirar livros gratuitamente nas bibliotecas públicas da cidade.

\section{O SUJEITO E A LEITURA}

Os dois subconjuntos que constituem esse conjunto temático contém relatos verbais que descrevem aspectos relacionados à leitura realizada pelos sujeitos entrevistados.

\section{Concepção de leitura dos sujeitos}

Nesse subconjunto, os sujeitos descrevem qual é, para eles, a função da leitura na sociedade atual; ao falar de "leitura", muitos salientam que ler é interpretar e não apenas decifrar, e afirmam que as pessoas têm muita dificuldade nessa interpretação do que é realmente a leitura, a importância que ela tem.

São atribuídas à leitura as funções de: formar opinião, permitir o acesso ao conhecimento, à cultura, melhorar $\mathrm{o}$ pensamento, o raciocínio, satisfazer as necessidades de estudo ou lazer, aumentar o nível de informação, enfim, ampliar a visão de mundo e, conseqüentemente, possibilitar às pessoas maior criticidade, provocando mudanças que contribuem para $o$ exercício da cidadania.

O que lêem

Procura-se descrever, nesse subconjunto, relatos sobre a leitura que os sujeitos entrevistados realizam: gênero, freqüência e procedência dos livros lidos.

Quanto à freqüência de leitura, há desde sujeitos que lêem apenas durante as férias e nos finais de semana, até 
aqueles que afirmam ler dois ou mais livros por dia.

Quanto à procedência, alguns sujeitos afirmam que preferem comprar os livros de seu interesse ao invés de retirá-los da biblioteca; dentre os que gostam de leituras relacionadas à sua área profissional, é consenso que a Biblioteca Central não consegue atender suas necessidades, não sendo possível recorrer ao empréstimo (apenas o assistente do setor braile, dada a especificidade do material, consegue utilizar mais amplamente o acervo existente na Biblioteca Central). Cabe ainda observar que poucos entrevistados têm carteirinha da biblioteca para empréstimo de livros, sendo feito um controle alternativo para os funcionários.

Com relação ao gênero dos livros que os sujeitos entrevistados lêem, percebese que a maior parte não tem afinidade com "romances" (livros de literatura), havendo uma certa preferência pelas obras sobre religião, Psicologia, autoajuda e livros técnicos.

Cabe ressaltar que, dentre todos os sujeitos, aquele que relata uma prática mais constante e efetiva de leitura é justamente a coordenadora que, por acreditar que poucos funcionários da Biblioteca Central são leitores, questiona como é que eles podem contribuir para a formação do gosto pela leitura.

\section{A FUNÇÃO SOCIAL DO BIBLIOTECÁRIO E DO ASSISTENTE DE BIBLIOTECA}

Esse subconjunto traz os relatos verbais em que os sujeitos entrevistados caracterizam sua prática no contexto da sociedade atual.
A maior parte acredita que a função do bibliotecário e do assistente, na sociedade de hoje, é passar informação, democratizá-la o máximo possível, já que a Biblioteconomia é a ciência da informação.

Essa preocupação justifica-se, segundo os sujeitos, pelo poder que a informação tem em um mundo globalizado; para um dos sujeitos, este poder deve ser ainda mais valorizado na sociedade brasileira, pois é a informação pública que vai possibilitar o exercício da cidadania, que vai fazer com que a pessoa participe mais, que saiba os seus direitos.

Em detrimento da parte mais técnica da Biblioteconomia, os relatos apontam para uma preocupação maior com o trabalho com o público; percebe-se, entretanto, que para alguns sujeitos não basta apenas conseguir a informação certa, para pessoa certa, no menor prazo de tempo possível, sendo fundamental estar sempre buscando formas de desenvolver nas pessoas o gosto pela leitura, o prazer de estar lendo pois, de um modo geral, as pessoas lêem muito pouco e isso acarreta uma desinformação muito grande.

Para a coordenadora, a função do bibliotecário na sociedade atual é social e cultural mas, no entanto, as pessoas não reconhecem isso. $\mathrm{O}$ próprio bibliotecário, segundo ela, dificilmente vê essa função. Ele pensa mais no lado técnico porque, durante sua formação, o que se enfatiza é o lado mais técnico e não a formação de leitores.

Um dos sujeitos acredita que o bibliotecário tem também a função de educador, pois é alguém ligado à cultura, cabendo a ele fazer a "ponte" até o povo, através da organização dessa cultura. Nesse sentido, estabelece um paralelo entre o bibliotecário e $\mathrm{o}$ 
professor que, para ele, são fundamentais $\mathrm{e}$ têm vivenciado $\mathrm{o}$ desprestígio da sociedade.

\section{AVALIAÇÃO DO SERVIÇO PRESTADO}

A avaliação que os sujeitos entrevistados fazem do serviço prestado pela Biblioteca Central é descrita nos três subconjuntos abaixo:

\section{Limitações}

Ao avaliar o serviço prestado pela Biblioteca Central, os sujeitos entrevistados apontam as seguintes dificuldades:

- acervo desatualizado, pois não há uma política de aquisição de material (a biblioteca vive de doações); deixa a desejar em termos de assuntos mais específicos e atuais; há poucos exemplares dos livros exigidos pelos principais vestibulares e de material para pesquisa; muito voltado à pesquisa escolar; especificamente no setor braile, há pouca produção de material;

- falta de pessoal (tanto bibliotecários como assistentes de biblioteca), o que sobrecarrega o trabalho de todos; torna o atendimento demorado, levando à formação de grandes filas no setor permanente; inviabiliza um trabalho de orientação à pesquisa; atrasa o processo de informatização do acervo, o que permitiria colocar as bibliotecas públicas em rede;

- depredação do acervo, tanto por não haver restrição para se tirar xerox do material, como pelo fato do usuário não ser consciente (o número limitado de funcionários não permite realizar um trabalho de educação);

- falta de espaço (tanto no setor destinado à pesquisa como no setor de braile);

- falta de leitores (que não apenas os estudantes);

- falta de clareza quanto à função social da biblioteca por parte dos funcionários, o que faz com que eles não tenham a noção de que é necessário convencer as pessoas da importância da biblioteca enquanto um serviço público.

Tendo em vista as limitações acima referidas, a maior parte dos sujeitos entrevistados considera insatisfatório o atendimento prestado pela Biblioteca Central e fazem suposições quanto ao tipo de mudanças que levariam à transformação da situação atual: a existência de um setor específico, na biblioteca, para a realização da pesquisa escolar; a ampliação do contacto entre escolas e bibliotecas públicas, procurando-se fazer um trabalho efetivo de orientação à pesquisa (ressalta a coordenadora que, por outro lado, a Biblioteca Central não pode assumir a função de biblioteca escolar, uma vez que não segue um projeto pedagógico).

Por fim, sugere-se que uma cidade com o porte e a renda de Campinas deveria ampliar seus investimentos na área de bibliotecas públicas, os quais têm sido ínfimos.

Reclamações

Ao relatarem as reclamações dos usuários sobre o serviço prestado pela Biblioteca Central, os sujeitos entrevistados afirmam que recebem 
desde reclamação no $156^{7}$ até agradecimentos, muitas vezes por parte de pessoas que não encontraram o material que procuravam mas que reconheceram o esforço do funcionário que as atendeu. Para alguns dos entrevistados, na medida do possível, os usuários saem satisfeitos porque as reclamações são decorrentes dos problemas que a biblioteca tem enfrentado de uma forma mais ampla.

Alguns sujeitos acreditam que o usuário não sabe reclamar pelos seus direitos da forma correta, pois não percebe, por exemplo, que o problema de demora da fila é reflexo da falta de um número maior de funcionários.

Com o aluno de $2^{\circ}$ grau, conforme afirmação de outro sujeito, o máximo que se consegue é uma discussão pessoal, às vezes um atrito, sendo que alguns, ao se sentirem insatisfeitos, ameaçam tirar o emprego de funcionários argumentando que $o$ salário destes é fruto dos impostos pagos pelo pai.

Para a coordenadora, o aspecto mais grave no serviço público é justamente o atendimento prestado pelos funcionários; a Biblioteca Central não foge à regra: atende mal o usuário (embora, salienta, haja exceções), sendo que a maior parte dos funcionários desconhece sua função social, sendo mão-de-obra pouco qualificada. Para tentar reverter esse quadro, a coordenadora tem incentivado a participação dos funcionários em eventos como o COLE (Congresso de Leitura do Brasil).

\footnotetext{
${ }^{7}$ Telefone que a Prefeitura de Campinas coloca à disposição dos cidadãos para informações, reclamações, etc. quanto aos serviços públicos da cidade.
}

Aspectos positivos

Dentre os sujeitos entrevistados, dois consideram que as pessoas, atualmente, saem satisfeitas da Biblioteca Central pelos seguintes motivos: porque $\mathrm{o}$ acervo supre a necessidade do usuário que necessita realizar sua pesquisa escolar ou ler revistas e todos fazem de tudo para não desapontar o usuário.

A maior parte dos sujeitos, entretanto, refere-se a aspectos positivos do serviço prestado pela Biblioteca Central precisamente em razão das limitações e dificuldades enfrentadas diariamente em seu cotidiano ou no serviço público de um modo geral: o setor braile, por exemplo, é considerado uma conquista por seus usuários, pois é um espaço que pode ser utilizado independentemente da entidade que freqüenta, sendo que o atendimento só é problemático, segundo um dos sujeitos, em decorrência das limitações do acervo.

Alguns dos sujeitos entrevistados enfatizam ainda que muitos problemas acabam por não aparecer porque alguns funcionários desdobram-se para não deixar as pessoas saírem sem algum material, característica que, para alguns, rompe com o esteriótipo que se tem do funcionário público que não trabalha.

\section{RELAÇÕES ENTRE A \\ BIBLIOTECA E A SECRETARIA MUNICIPAL DE EDUCAÇÃO}

Os dois subconjuntos abaixo descrevem a interação existente entre a Biblioteca Central e a Secretaria Municipal de Educação, à qual ela está subordinada, tendo em vista dois aspectos: investimentos e política (ações e projetos). 
Investimentos

Ao falar das condições propiciadas pela Secretaria Municipal de Educação à Biblioteca Central, a maior parte dos sujeitos relata que ele é ínfimo; alguns afirmam que se deve levar em consideração que há um problema orçamentário mais amplo, que obriga a Prefeitura a realizar cortes de verba; no caso da Secretaria Municipal de Educação de Campinas, alguns sujeitos acreditam que a prioridade de investimento devem ser as escolas.

Por outro lado, um aspecto é insistentemente relatado: não há uma política de atualização de acervo, de aquisição de material (a última compra de livros ocorreu em 1995, após 15 anos sem que tivesse havido qualquer aquisição) e nem uma política de leitura para a cidade, o que obriga a Biblioteca Central a procurar alternativas para conseguir minimamente se manter.

De um modo geral, os sujeitos consideram irrisório o investimento que se faz em Educação e Cultura, tanto no município de Campinas como em termos nacionais, sendo que essas áreas deveriam de fato ser consideradas prioritárias.

Um dos sujeitos compara a quantidade de bibliotecas existentes em Campinas com as da cidade de São Paulo e conclui que a Biblioteca Central deveria ter pelo menos o triplo do tamanho, dada a sua localização $\mathrm{O}$ mesmo sujeito reflete que, em termos de doações, não há uma preocupação nem por parte das universidades nem das editoras de enviar material para as bibliotecas públicas de Campinas, pois esta atende principalmente um público de menor poder aquisitivo que não adquire livros, limitando-se a emprestá-los da biblioteca ou a tirar xerox. Para este sujeito, os serviços considerados essenciais deveriam ter um orçamento próprio, ser auto suficientes, talvez até independentes da verba da Prefeitura.

Outro sujeito argumenta que o precário investimento na área da Educação (uma das áreas consideradas prioritárias), tanto em termos municipais como nacionais, tem levado a um desestímulo à leitura, pois a carência de verbas não tem permitido seu incentivo.

\section{Política}

Ao procurar descrever ações e projetos da Secretaria Municipal de Educação e da Biblioteca Central (às vezes em conjunto com outros órgãos), no sentido de democratizar a leitura no município de Campinas, alguns sujeitos afirmaram não ter muito conhecimento sobre essa questão, a qual poderia ser melhor esclarecida junto à coordenadora.

Um projeto, entretanto, que estava sendo implantado no período em que as entrevistas foram realizadas (na verdade, trata-se de uma nova "versão" de um projeto anterior, que já vinha sendo realizado), era do conhecimento de todos: "Leitura, Música e Companhia", que consiste em uma visita programada de escolas à Biblioteca Central, para mostrar seu espaço, suas atividades, seu acervo, bem como realizar um trabalho de conscientização sobre a necessidade de conservação do acervo. Ao término da visita, os alunos assistem a um show musical, com artistas locais ou um coral.

Para alguns sujeitos, esse tipo de projeto, voltado ao público infantil, pode contribuir para uma futura transformação do espaço da biblioteca em um centro de cultura, de leitura, de promoção da leitura, freqüentado por adultos mais conscientes da importância do ato de ler. 
Além do projeto "Leitura, Música e Companhia", houve referência a algumas outras iniciativas da biblioteca: concurso de poesia (realizado em 1998); um projeto em parceria com uma empresa que envolveu a doação de livros novos; leitura em asilo. Também a parceria com o Programa Nacional de Incentivo à Leitura (PROLER) foi mencionada, sendo a Biblioteca Central a sede do PROLER em Campinas (até aquela ocasião, dentre os vários projetos em estudo nenhum havia sido implantado).

Para um dos sujeitos, projetos como os realizados pelo PROLER, ou o "Leia Brasil" tem uma abrangência restrita, pois poucas escolas públicas são contempladas com eles, sendo a sala de aula e a biblioteca locais privilegiados de formação de leitores.

Para a coordenadora, em termos de ações e projetos relacionados com o incentivo à leitura, pouco tem sido feito no espaço das bibliotecas públicas de Campinas; no entanto, ela enfatiza que para realizar atividades diferenciadas como, por exemplo, sessões de leitura, debates com escritores, tendo em vista a abertura estratégica de espaços que consigam trazer outro público para a biblioteca é necessário ampliar o espaço físico disponível e, ao mesmo tempo, contar com a atuação de bibliotecários com uma visão mais social de sua função, o que tem sido dificultado pela ênfase ainda dada à parte mais técnica nos curso de Biblioteconomia.

Através de um outro projeto, denominado "Bibliotecas Itinerantes" (que deveria ser iniciado em abril), envolvendo parceria entre a PUCC, FAPESP e a Secretaria Municipal de Educação, pretende-se, conforme esclarece a coordenadora, mapear Campinas tendo em vista suas diversas regiões e, partindo-se do pressuposto de que as pessoas não lêem porque $\mathrm{o}$ acesso à biblioteca não se dá, será feito um levantamento sobre as necessidades específicas das diferentes parcelas da população.

Embora os projetos já realizados ainda não tenham despertado o interesse da população de uma forma mais ampla, acredita-se que a continuidade dos mesmos seja fundamental, pois é através dessas atividades que se pretende conseguir modificar a imagem que a população tem da biblioteca, expandindo-se o contacto dos moradores de Campinas com a leitura.

\section{Dados das fichas cadastrais}

Dentre o total de aproximadamente 8500 fichas cadastrais existentes no fichário do setor circulante, 384 delas atendiam as condições preestabelecidas na presente pesquisa: apresentar profissão e idade do usuário. Mesmo não sendo uma amostra tão representativa em termos numéricos (cerca de $5 \%$ do total das fichas cadastrais), os dados apresentados mostraram-se significativos, razão pela qual foram incluídos na análise.

Após o levantamento dos dados através da leitura de cada uma das fichas cadastrais (uma vez que o setor circulante, como os demais, ainda não foi informatizado), organizaram-se as informações sobre as categorias profissionais e a faixa etária dos usuários na tabela $\mathrm{e}$ nas figuras apresentadas nas páginas seguintes.

Quanto às categorias profissionais, as mais representativas foram a 9 (estudantes) e a 4 (ocupações nãomanuais de rotina e assemelhadas - que incluem, por exemplo, professor primário, secretária, auxiliar de escritório, vendedor, policial, bancário, datilógrafo, etc.), atingindo, 
respectivamente, $48,70 \%$ e $29,69 \%$ do total das fichas selecionadas.

Com exceção da categoria 1 (altos cargos políticos e administrativos, proprietários de grandes empresas e assemelhados) que não apareceu, as demais atingiram uma porcentagem não superior a 5,99\%, índice alcançado pela categoria 6 (ocupações manuais especializadas e assemelhadas como, por exemplo, eletrecista, motorista, músico de banda, técnico de TV, etc).

Em termos de idade, 41,93\% dos usuários da amostra encontram-se na faixa etária que vai de 20 a 29 anos, seguidos pelas pessoas que estão na faixa dos 8 aos 19 anos, que atingem o índice de $31,25 \%$. Tendo em vista as fichas cadastrais analisadas, poucos usuários têm acima de 50 anos: 1,82\% têm de 50 a 59 anos e 1,30\% estão na faixa que vai dos 60 aos 69 anos.

Cruzando-se os dados referentes à categoria profissional e à faixa etária, é possível traçar $o$ seguinte perfil preliminar dos usuários do setor circulante: em sua maioria, são estudantes que têm entre 8 e 29 anos de idade $(73,18 \%)$; do total de 187 estudantes inclusos na categoria 9, $57,21 \%$ têm entre 8 a 19 anos, seguidos de perto pelos que estão na faixa dos 20 aos 29 anos $(41,17 \%)$.

\section{Dados das planilhas de retirada de livros}

As planilhas permitem visualizar o movimento mensal de retirada de livros do setor circulante (organizados, pela bibliotecária, em classes), sendo que o período de referência para esta pesquisa vai de março de 1998 a março de 1999

\footnotetext{
${ }^{8}$ Indica-se o intervalo de idade a partir dos 8 anos porque, dentre as fichas da análise, não se constatou a existência de usuários com idade inferior.
}

(não houve registro no mês de janeiro de 1999, pois a Biblioteca Central permaneceu fechada).

De um modo geral, os dados permitem detectar tanto a preferência de leitura dos usuários, como os períodos de maior e menor freqüência de retirada de livros do setor circulante.

A partir da totalização dos dados presentes nas planilhas, referentes à quantidade de cada uma das classes de livros retiradas mensalmente, organizou-se a Tabela 2 que apresenta os números totais e porcentagens de retiradas de livros (por classe) correspondentes ao período de março de 1998 a março de 1999.

\section{TABELA 1}

Números totais e porcentagens de retiradas de livros (por classe), no período de março de 1998 a março de 1999

\begin{tabular}{r|r|r|l}
\hline & \multicolumn{2}{|c|}{ TOTAL } & *CLASSES: \\
\hline${ }^{*}$ Classes & \multicolumn{1}{|c}{ Qtd } & \multicolumn{1}{c}{$\%$} & \\
\hline 800 & 15216 & $47,5 \%$ & 000 - Obras Gerais \\
\hline 100 & 3478 & $10,9 \%$ & 100 - Filosofia \\
\hline 028.5 & 2117 & $6,6 \%$ & 200 - Religião \\
\hline Vestibular & 1940 & $6,1 \%$ & 300 - Ciências Sociais \\
\hline 300 & 1896 & $5,9 \%$ & $\begin{array}{l}400 \text { - Lingüística / } \\
\text { Línguas }\end{array}$ \\
\hline 600 & 1622 & $5,1 \%$ & 500 - Ciências Puras \\
\hline 500 & 1386 & $4,3 \%$ & $\begin{array}{l}600 \text { - Medicina / Adm / } \\
\text { Eng }\end{array}$ \\
\hline 900 & 952 & $3,0 \%$ & 700 - Artes \\
\hline Biografia & 881 & $2,7 \%$ & 800 - Literatura \\
\hline 200 & 719 & $2,2 \%$ & $\begin{array}{l}\text { 900 - História / } \\
\text { Geografia }\end{array}$ \\
\hline $\begin{array}{r}\text { Apostilas } \\
\text { Fotocópias }\end{array}$ & 605 & $1,9 \%$ & $\begin{array}{l}\text { O28.5 - Literatura } \\
\text { Infanto-Juvenil }\end{array}$ \\
\hline 000 & 479 & $1,5 \%$ & Biografias \\
\hline 400 & 391 & $1,2 \%$ & Apostilas / Fotocópias \\
\hline 700 & 366 & $1,1 \%$ & $\begin{array}{l}\text { Vestibular: livros } \\
\text { indicados para os } \\
\text { vestibulares }\end{array}$ \\
\hline Total & $\mathbf{3 2 0 4 8}$ & $\mathbf{1 0 0 , 0 \%}$ & \\
\hline & &
\end{tabular}

Nesse período, foi retirado um total de 32.048 livros, sendo que a média mensal de retirada foi de cerca de 2670 livros. 
É possível constatar, entretanto, que esta média sofre uma queda nos meses de dezembro/1998 e fevereiro/1999, registrando, respectivamente, 1995 e1662 livros; por outro lado, há um aumento de retirada nos meses de setembro/1998 (3100 livros) e março/1999 (3005 livros).

Observa-se, em todos os meses registrados, que a classe de livros mais retirada pelos usuários é a referente à Literatura (800), alcançando o índice de $47,5 \%$ do total de livros emprestados. É possível detectar que, mesmo nos meses em que há um decréscimo no total de livros retirados, a porcentagem de livros de Literatura emprestados mantém-se na média.

Quanto às outras classes, os índices são bem menores, sendo que a segunda classe mais retirada (100 - Filosofia) atingiu $10,9 \%$; a que obteve o menor índice foi a classe 700 (Artes), com $1,1 \%$.

\section{DISCUSSÃO DOS DADOS}

Conhecer a dinâmica de funcionamento da Biblioteca Pública Municipal "Prof. Ernesto Manoel Zink", objetivo dessa pesquisa, relaciona-se a uma problemática maior: investigar se esse espaço público tem representado, para os moradores de Campinas, uma possibilidade de inserção no mundo da escrita, um ambiente de letramento.

A fundamentação teórica, apresentada na introdução desse trabalho, remete a novas exigências na formação de um cidadão leitor e produtor de textos, tendo em vista as mudanças sóciopolítico-econômicas advindas do avanço tecnológico.

Como esclarece SOARES (1998), há uma diferença entre saber ler e escrever (ser alfabetizado) e viver na condição ou estado de quem sabe ler e escrever (ser letrado). A condição de "letrado" implica o uso social, de forma freqüente e competente, da leitura e da escrita (e não apenas saber ler e escrever), respondendo-se adequadamente às demandas sociais de leitura e escrita. Esclarece ainda SOARES (1998) que "o nivel de letramento de grupos sociais relaciona-se fundamentalmente com as suas condições sociais, culturais e econômicas" (p. 58), sendo necessário haver condições para o letramento.

Uma primeira condição para isto, segundo ela, é que haja escolarização real e efetiva da população (o que vai além de simplesmente ensinar a ler e escrever); uma segunda condição para o letramento é que haja disponibilidade de material de leitura:

“O que ocorre nos países de
Terceiro Mundo é que se
alfabetizam crianças e adultos,
mas não lhe são dadas as
condições para ler e escrever:
não há material impresso posto à
disposição, não há livrarias, o
preço dos livros e até dos jornais
e revistas é inacessível, há um
número muito pequeno de
bibliotecas. Como é possível
tornar-se letrado em tais
condiçães?” (p. 58$)$

A questão do acesso ao material impresso, portanto, é fundamental pois, para participar do mundo letrado, é preciso vivenciar condições sociais em que a leitura e a escrita tenham uma função, tornando-se uma necessidade e uma forma de lazer.

FOUCAMBERT (1994) considera necessário um processo de desescolarização da leitura, pois entende que esta é um aprendizado social, sendo que as medidas paliativas contra o analfabetismo deveriam ser substituídas por um processo de 
leiturização, que consiste numa opção política global, pois o aprendizado da leitura, pela forma como vem se concretizando, faz com que iletrados e não-leitores vivenciem um processo de exclusão das redes de comunicação escrita, não sendo considerados destinatários dos escritos presentes em seu ambiente, deixando de se beneficiarem de uma real relação com a escrita, ou seja, não têm o estatuto de leitores, não percebendo a possibilidade de ampliação do poder através de sua inserção no universo da palavra escrita, ou seja, ignoram que o acesso ao universo da leitura é condição necessária para o exercício da cidadania.

Assim, em uma perspectiva política, as condições de letramento extrapolam o campo das ações individuais $\mathrm{e}$ envolvem questões mais amplas de política social, revelando que outras condições, de ordem sócio-política e econômica, como afirma SILVA (1997), são necessárias para que a prática da leitura seja efetivamente exercida. É desta perspectiva que se pretende interpretar os dados apresentados nessa pesquisa quanto à dinâmica de funcionamento da Biblioteca Central.

Como a descrição dos dados evidencia, a cidade de Campinas não tem uma efetiva política de leitura: o investimento que se faz nessa área é ínfimo, sendo que, como bem salientou um dos sujeitos entrevistados, é espantoso que uma cidade de seu porte conte com apenas quatro bibliotecas públicas, nenhuma delas localizada em bairros onde se encontram as camadas mais pobres da população.

Além disto, as dificuldades enfrentadas pelos bibliotecários e assistentes da Biblioteca Central, em seu cotidiano, são muitas, envolvendo, principalmente, limitações com relação ao acervo (pois não há uma política de aquisição de material), número insuficiente de funcionários (o que acarreta sobrecarga de trabalho, filas no balcão de atendimento do setor permanente, inviabiliza um trabalho de orientação à pesquisa, etc.).

Outras duas limitações têm uma importância fundamental para se entender, de forma mais ampla, um problema que diz respeito, não só à Biblioteca Central de Campinas, mas às bibliotecas públicas de um modo geral: o número reduzido de leitores, que não apenas estudantes, e a falta de clareza quanto à função social da biblioteca, por parte dos funcionários.

Com relação ao primeiro desses aspectos, cabe ressaltar que, praticamente, em todos os relatos verbais, afirmou-se que a Biblioteca Central tem funcionado como uma biblioteca escolar, atendendo basicamente estudantes de $1^{\circ}$ e $2^{\circ}$ graus de escolas públicas municipais $\mathrm{e}$ estaduais (raramente de escolas particulares), que trabalham de dia e estudam à noite, residem na periferia e utilizam a Biblioteca Central quase que exclusivamente para pesquisa escolar.

Como enfatizaram alguns dos sujeitos entrevistados, essa situação não é específica da Biblioteca Central de Campinas, pois as bibliotecas públicas, de um modo geral, acabam tendo que suprir a escassez de bibliotecas escolares, o que faz com que o usuário, que não dispõe de recursos financeiros (que lhe permitiria, por exemplo, comprar um livro ou acessar a Internet), tenha como único apoio o acervo disponível nesses espaços.

Embora também conte com uma reduzida comunidade leitora (formada pelas pessoas que lêem jornal, donas- 
de-casa que gostam de ler romance e crianças que apreciam literatura infantojuvenil, além dos estudantes que se vêem obrigados a ler os livros indicados para os vestibulares), é o setor permanente, onde são realizadas as pesquisas, o "carro-chefe" da Biblioteca Central; isto parece incomodar os sujeitos entrevistados pelos dois motivos explicitados a seguir.

O primeiro deles é que se acredita que a biblioteca pública deveria ter uma outra função e um outro público, devendo-se constituir no local onde o usuário pode ter acesso à leitura de lazer e a informações que lhe possibilitem aprimorar o exercício de sua cidadania; o público-alvo da biblioteca pública, portanto, seria formado por pessoas conscientes do valor da leitura para suas vidas e que entendem o espaço público da biblioteca como um local a que têm direito, dele desfrutando enquanto um ambiente que possibilita condições de letramento. É precisamente este leitor que está em falta...

Vale lembrar que a coordenadora afirmou, em sua entrevista, ter ouvido de antigos freqüentadores do setor circulante da biblioteca que, antigamente, este local tinha mais função na vida deles, desde a infância até a idade adulta, pois não se costumava comprar livros mas emprestá-los da biblioteca, sendo que as pessoas tinham hábito ou gosto pela leitura. Com relação ao hábito de ler, verifica-se, pelas entrevistas, que os próprios sujeitos, em sua maioria, ficam aquém das próprias expectativas que têm com relação à leitura dos usuários (há os que se dizem leitores apenas durante as férias profissionais, por exemplo; muitos que não gostam de ler literatura em prosa), sendo que poucos recorrem ao acervo da própria biblioteca.
SILVA (1995), em palestra proferida no $13^{\circ}$ COLE, em julho de 1985, propunha o seguinte contraponto: "leitura em crise $x$ gosto pela leitura", argumentando que a dominação de uma classe sobre as outras (principalmente em termos econômicos) "pré-estabelece um conjunto de convenções para o desenvolvimento e para o exercício da atitude estética", sendo que, na ótica burguesa, "as concepções de leitura, as obras a serem privilegiadas para a leitura da população, os locais para ler... são arbitrariamente convencionalizados no sentido de servir como modelo exemplar para todo o conjunto da sociedade”. Deste modo, segundo o autor, sacralizou-se a noção de leitura como um ócio descompromissado, desligado do trabalho produtivo e a idéia de biblioteca como "um museu estagnado ou como receptáculo passivo, nada influindo no seu contexto; a noção de leitor 'culto', que deve ler determinadas obras e não outras." (p.46)

Essas afirmações são importantes, pois muitos dos sujeitos entrevistados, ao enfatizarem a necessidade de haver um público leitor, acabam por evocar o "modelo exemplar" de leitor, cuja leitura se dá apenas por lazer. Deve-se esclarecer, entretanto, que pensar em condições de letramento, ou seja, em possibilidades de uma prática efetiva da leitura e da escrita na sociedade, não exclui a leitura realizada também por necessidade, desde que esta tenha significação para o sujeito que a realiza.

Um segundo aspecto que desagrada bibliotecários e assistentes, com relação ao setor permanente, é o modo como os estudantes realizam sua pesquisa escolar: de forma mecânica, sem haver uma leitura prévia para seleção de informações, tudo não passando, como sugeriu um dos entrevistados, de uma "gincana de tirar xerox", sendo que os 
usuários não dominam os mecanismos que poderiam auxiliá-los (como uma bibliografia de referência, índices, sumários, etc.), o que é visto como conseqüência da decadência do ensino no país.

Este é o público majoritário da Biblioteca Central: pessoas de uma classe social mais baixa, que foram alfabetizadas pela escola (algumas, como sugerem certos relatos, têm dificuldades até mesmo com relação à técnica do ler e escrever...) e que seguem sua trajetória escolar sem estabelecer com a escrita e a leitura um contacto significativo, pois o tipo de atividade que realizam (no caso, a pesquisa escolar), nos moldes exaustivamente apontados pelos sujeitos entrevistados (não sabem nem ao certo o tema da pesquisa, que muitas vezes o professor retirou do título de um capítulo do livro didático; sequer lêem o material fornecido, dirigindo-se automaticamente à fila do xerox), não se constitui em uma prática social, são materiais produzidos exclusivamente para serem entregues ao professor (que, supõe-se, raramente lê o material "produzido" pelos alunos).

Desse modo, evidencia-se que justamente a parcela da população que é excluída das redes de comunicação, como afirma FOUCAMBERT (1994), acaba por deixar de vivenciar condições de letramento nos poucos espaços em que isto lhe seria possível: na escola e na biblioteca, pois ambos têm apenas reforçado a falta de significação no contacto com a leitura, desconsiderando-se suas funções críticas:

"Se concebermos o processo de leitura como um instrumento civilizatório de reflexão $e$ compreensão da realidade $e$, por isso mesmo, de inserção do homem na história e no seu tempo

através da análise crítica dos
registros ou documentos
veiculados pela escrita, as
funções sociais da leitura estão
amarradas ao processo de
conscientização ou politização
dos brasileiros e aos seus
movimentos de luta por uma
sociedade diferente da atual.”
(SILVA, 1995, p.17)

Conseqüentemente, tanto no setor circulante (que também é muito freqüentado por estudantes, pois é há um aumento e diminuição da retirada de livros precisamente nas época do ano que correspondem aos períodos letivo e de férias escolares, respectivamente), como no setor permanente e mesmo no setor braile (que funciona mais como um espaço socializante) faltam leitores, ou seja, sujeitos "letrados", no sentido que SOARES (1998) dá a esse termo: pessoas que fazem uso social, de forma freqüente e competente, da leitura e da escrita, respondendo adequadamente às demandas sociais que envolvem essas duas práticas (e não o leitor burguês exemplar, referido por SILVA, 1995)

Nesse contexto, convivendo com usuários que, de um modo geral, não compartilham de boas condições de letramento e, por isso, deixam de estabelecer um contacto mais crítico com os materiais impressos, é imprescindível analisar que função bibliotecários e assistentes da Biblioteca Central atribuem ao seu trabalho, bem como refletir sobre os projetos em estudo ou que vêm sendo realizados pela Secretaria Municipal de Educação, no sentido de democratizar a leitura na cidade de Campinas.

$\mathrm{O}$ primeiro aspecto remete a uma outra limitação apontada pela coordenadora da Biblioteca Central: a falta de clareza com relação à função social da biblioteca por parte dos funcionários, referindo-se à dicotomia existente entre a parte mais técnica e a 
parte mais social e cultural da Biblioteconomia.

SILVA (1995), ao discutir a dimensão pedagógica do trabalho do bibliotecário, em palestra proferida em 1985, faz um breve retrospecto sobre as mudanças ocorridas no campo da Biblioteconomia e da Educação, no final da década de 70 e início dos 80, em função do questionamento do "tecnicismo" que imperava, o que levou tanto a escola como a biblioteca a perceberem com maior clareza a relação de suas funções com a política do contexto social, passando o bibliotecário a ser considerado um "agente cultural de mudança", sendo seu trabalho de cunho político.

Nesse sentido, esclarece SILVA (1995), a difusão da informação (que era antes considerada uma atividade apenas técnica) ganhou uma outra dimensão, sendo necessário que a biblioteca "exerça influência ativa e dinâmica no contexto envolvente, preocupando-se com a qualidade do seu acervo e dos seus serviços, com a origem $e$ necessidade de seus usuários, com a democratização do seu espaço e com o planejamento de programas sócioculturais" (p. 72)

É interessante observar que os sujeitos entrevistados, principalmente os bibliotecários, revelaram até um certo preconceito com relação à parte mais técnica da Biblioteconomia, procurando enfatizar sua preferência pelo trabalho com o público. Há, entretanto, uma diferença de entendimento sobre o que vem a ser um trabalho de cunho social e cultural no âmbito da biblioteca.

Para a maioria, ele implica em garantir ao usuário o acesso à informação, de forma rápida e eficaz. Alguns dos sujeitos entrevistados, entretanto, também consideram este tipo de trabalho como algo mais "técnico", consequiência de uma formação que ainda enfatiza muito esse aspecto. Para esses sujeitos, o que caracteriza uma atuação realmente social e cultural do bibliotecário é a formação de leitores, bem como conseguir trazer para o espaço da biblioteca aqueles que já vivenciam condições de letramento.

Assim, no contexto da Biblioteca Central, as duas principais limitações detectadas (falta de leitores e de clareza quanto à função social da biblioteca por parte dos funcionários) estão diretamente relacionadas, pois uma das funções do bibliotecário, numa perspectiva mais social, é, como afirma SILVA (1995), preocupar-se com a origem e necessidade de seus usuários que, como vimos, representam uma maioria que tem sido excluída das condições de letramento.

Desse modo, é fundamental que os funcionários da Biblioteca Central desenvolvam ações no sentido de conseguir concretizar um dos objetivos a que se propõem: "auxiliar o aluno a adquirir um mecanismo fundamental da sociedade informativa: o hábito da pesquisa", tendo em vista um objetivo mais amplo: a formação do leitor. Para isso, será preciso vencer, como assinala SILVA (1995), o divórcio existente entre bibliotecários e professores, para que ambos consigam dar mais ênfase à dimensão educativa de suas práticas e elaborar programas para $o$ desenvolvimento do gosto pela leitura e para a formação integral do leitor, através de diálogos mais freqüentes, geradores de propostas conjunta.

Por outro lado, como os dados permitem detectar, são ínfimos os investimentos por parte da Prefeitura de Campinas na área de bibliotecas públicas, o que acaba por dificultar bastante a implentação de projetos; mas, como argumenta SILVA (1995), não se 
deve adotar uma atitude de dependência, "temos que atuar politicamente em nossos contextos; esperar que alguém destine alguma política é continuar esperando..." (p.79)

Assim, dentre os poucos projetos já implementados na Biblioteca Central, um deles, que envolve a participação de alunos de escolas públicas municipais ("Leitura, Música \& Companhia) tem servido como um primeiro passo na aproximação entre $\mathrm{o}$ professor $\mathrm{e} \quad \mathrm{o}$ bibliotecário, buscando também mudar a imagem que o público em geral tem da biblioteca, motivando-o a ver este espaço e a leitura como bens públicos a que tem direito de ter acesso.

Entretanto, conforme afirma BRITO (1998), incentivar a leitura efetivamente, como bem público, como marca de cidadania, exige que não se desconsidere que, “... como a leitura se faz em função da manipulação de sistemas específicos de referência $e$ interpretação, sistemas constituídos histórico-socialmente, é razoável supor que ela vem sendo quase propriedade dos segmentos sociais que dispõem de condições sócio-econômicas privilegiadas...", o que implica que uma campanha social pela leitura deve ser postulada como um direito a ser conquistado por aqueles que de fato são excluídos da leitura: "Trata-se de outra face da disputa político-social pelo poder, assim como a luta pela terra, por habitação, por trabalho, por saúde $e$ educação". ( p.2)

\section{REFERÊNCIAS BIBLIOGRÁFICAS}

BAKHTIN, M. Marxismo e filosofia da linguagem. 8.ed. São Paulo : Hucitec, 1997.
BENVENISTE, E. Da subjetividade na linguagem. In: PROBLEMAS de lingüística geral I . Campinas, SP: Pontes ; Ed. UNICAMP, 1991.

BOGDAN, R. e BIKLEN, S. Investigação qualitativa em educação - uma introdução à teoria e ao método. Porto: Porto Editora, 1991.

BRASIL. Ministério da Educação e do Desporto. Parâmetros curriculares nacionais : Língua Portuguesa. Brasília, DF : SEF, 1997.

BRITO, Luiz P. L. Promoção da leitura e cidadania. Folha Proler, Rio de Janeiro, v.2, n.5, set. 1998.

CHARTIER, R. A história cultural: entre práticas e representações. Lisboa : Difel, 1990.

FOUCAMBERT, J. A leitura em questão. Porto Alegre : Artes Médicas, 1994.

FOUCAULT, M. Vigiar e punir : nascimento da prisão. Petrópolis : Vozes, 1991.

GOODMAN, K. S. Reading a psycholinguistic guessing game. In: SINGER, H., RUDDELL, R. G. (Org.). Theorical models and processes of reading. Newark, Delaware : IRA, 1996.

GROTTA, Ellen B. C. Histórias de relações críticas com a leitura: trajetória de um compromisso político. Campinas, SP : [s.n.], 1998. (Projeto de pesquisa)

LÜDKE, M., ANDRÉ, M. E. D. Perspectivas em educação : abordagens qualitativas. São Paulo: EPU, 1986. 
SILVA, Ezequiel T. da. Leitura na escola $e$ na biblioteca. 5.ed. Campinas, SP : Papirus, 1995.

- Leitura \& realidade brasileira. Porto Alegre : Mercado Aberto, 1997.

SMITH, F. Compreendendo a leitura : uma análise psicolingüística da leitura $e$ do aprender a ler. 4.ed. Porto Alegre : Artes Médicas, 1989.

SOARES, Magda B. Língua escrita, sociedade e cultura - relações, dimensão e perspectiva. Revista Brasileira de Educação, São Paulo, n.0, set./dez. 1995.

\section{Presenca Horizonte, n.2, n10, jul./ago. 1996.}

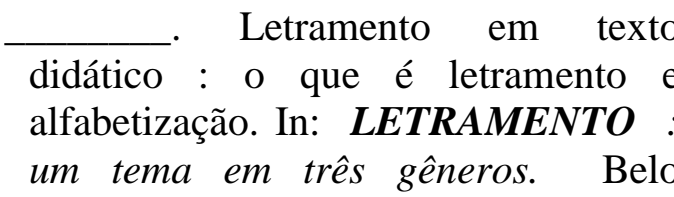
Horizonte : Ceale/Autêntica, 1998.

TERZI, Sylvia B. A construção da leitura : uma experiência com crianças de meios iletrados. Campinas, SP: Ed. UNICAMP, 1995.

VYGOTSKy, L. S. Pensamento e linguagem. São Paulo : Martins Fontes, 1993 (Psicologia e Pedagogia). 